\title{
Potassium induced salinity tolerance in wheat (Triticum aestivum L.)
}

\author{
${ }^{1}$ M. U. Shirazi, ${ }^{2 *}$ M. Y. Ashraf, ${ }^{1}$ M. A. Khan and ${ }^{1}$ M. H. Naqvi \\ ${ }^{1}$ Nuclear Institute of Agriculture, Tando Jam, Sindh, Pakistan \\ ${ }^{2}$ Stress Physiology Liboratory, Nuclear Institute for Agriculture and Biology (NIAB), P. O. Box 128, \\ Jhang Road, Faisalabad, Pakistan
}

Received 7 May 2005;

revised 10 June 2005;

accepted 17 July 2005;

onlined 30 September 2005

\begin{abstract}
Water culture experiments were conducted to study the response of ten wheat genotypes to external K application

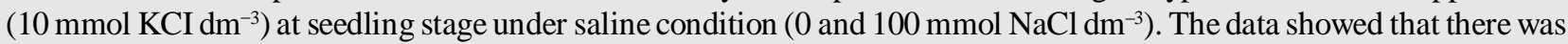
an increase in the shoot and root length with the application of external K. The increase was more pronounced under control than under saline conditions. The better performing genotypes under two treatments were Bhitai, NIAB-41, NIAB-I076 and Khirman. The enhanced growth of these genotypes under saline condition might be due to the quick response to external $\mathrm{K}$ application, resulting in high $\mathrm{K} / \mathrm{Na}$ ratio. The results indicated that the genotypes, which have the ability of enhanced $\mathrm{K} / \mathrm{Na}$ discrimination, might perform better under saline conditions when sufficient potassium is applied in the rooting medium.
\end{abstract}

Key words: Potassium, salt tolerance, wheat, $\mathrm{K}^{+} / \mathrm{Na}^{+}$ratio

*Corresponding Author, E-mail: niabmyashraf@yahoo.co.uk

\section{Introduction}

Wheat is commonly classified as a moderately salt tolerant crop (Mass and Hoffman, 1977). The threshold value for wheat is about $7 \mathrm{dS} / \mathrm{m}$ corresponding to $4480 \mathrm{mg} / \mathrm{l}$. Salt tolerance in wheat is mostly related to its enhanced ability to discriminate between $\mathrm{K}$ and Na during transport of these ions to the shoot (Gorham, 1990). It has been reported that in wheat (hexaploid), the 4D chromosome, derived from the wild grass Aegilops squarrosa is responsible for salt tolerance and $\mathrm{K}^{+}$) $\mathrm{Na}^{+}$discrimination character (Shah et al., 1987). Potassium contributes more than $\mathrm{Na}^{+}, \mathrm{Cl}^{-}$and glycinebetaine in osmotic adjustment under saline conditions (Ashraf and Sarwar, 2002).

Addition of external $\mathrm{K}^{+}$alone or in combination with $\mathrm{P}$ and $\mathrm{Ca}$ to saline medium significantly increases $\mathrm{K}^{+} / \mathrm{Na}^{+}$ratio in the leaf, stem and root (Epstein, 1966). This increased uptake of $\mathrm{K}$ could result a direct competition between $\mathrm{K}^{+}$and $\mathrm{Na}^{+}$at sites of uptake in plasmalemma (Epstein, 1966), an effect of $\mathrm{K}^{+}$on $\mathrm{Na}^{+}$transport into xylem and/or a $\mathrm{K}^{+}$induces net extrusion from roots (Jeschke and Nassery, 1981 and Munns et al., 1983). However, there exists some variation within the species/ genotypes for $\mathrm{Na}^{+}$accumulation and for discrimination in favour of $\mathrm{K}^{+}$transport to shoot (Gorham, 1990). Therefore, a study was planned to investigate the response of some local advanced wheat genotypes to $\mathrm{K}^{+}$application and to explore a suitable $\mathrm{K}^{+}$dose for enhancing salt tolerance of wheat.

\section{Materials and Methods}

A series of experiments were conducted to observe the response of ten wheat genotypes (Khirman, Sarsabz, Bhitai, RWM-9313, ESW-9525 H.T-29, NIAB-41, NIAB-1076 and NIAB-886) to external $\mathrm{K}^{+}$application at early seedling stage under saline conditions using nutrient solution $\left(\mathrm{l} / 4^{\text {th. }}\right.$ strength Hoagland solution). Salinity was induced by a sodium salt $\left(0\right.$ and $100 \mathrm{mmol} \mathrm{NaCl} \mathrm{\textrm {dm } ^ { - 3 }}$ ). External potassium $(\mathrm{K})$ was applied in the form of $\mathrm{KCl}$ to

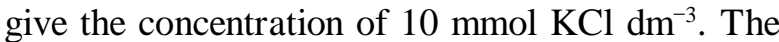
experiments were conducted in randomized manner with three replicates and were terminated after one week. Growth observations were recorded in terms of shoot and root length. Ionic contents ( $\mathrm{Na}$ and $\mathrm{K}$ ) in plant shoot were determined after extraction with 0.1M acetic acid $\left(\mathrm{CH}_{3} \mathrm{COOH}\right)$, Jackson (1962).

\section{Results}

The data for shoot and root growth is presented in Table 1. The results show that under control conditions all the wheat genotypes responded positively to external $\mathrm{K}^{+}$application, except NIAB- 
886. Whereas, under salinity treatment $(100 \mathrm{mM}$ $\mathrm{NaCl}$ ), five of the tested varieties showed increased shoot length while the remaining five genotypes (NIA-886, RWM-9313, Sarsabz, H.T-37 and ESW9525) have shown a decrease in the shoot length. The maximum shoot length was observed in Bhitai followed by NIAB-41 and NIAB-1076. The differences were significant within the treatments and within the genotypes. Root length of the wheat genotypes was also improved by the application of external $\mathrm{K}$ application. Increase was more pronounced under control conditions than under salinity. The genotype Bhitai showed maximum response to $\mathrm{K}$ application, both under control as well as under salinity treatment followed by Khirman. The two genotypes NIAB-41 and NIAB-I076, which were showing positive trend in the case of shoot length, exhibited a reversed trend in the case of root length. The differences were significant within the genotypes as well as within the treatments. The data for ionic contents is presented in table 2 . Sodium concentrations in different wheat genotypes increased with increasing salinity treatments. However, there was a decrease in the sodium content with the external $\mathrm{K}^{+}$application. Maximum sodium accumulation was observed in genotypes ESW-9525, whereas, accumulation was lowest in NIAB-l 076. Potassium application also resulted in increased concentrations of potassium in plants under both conditions (control and salinity). Maximum potassium contents were recorded in Bhitai and NIAB-I076 under control and saline treatment, respectively. The $\mathrm{K}^{+} / \mathrm{Na}^{+}$ratio in plant shoots also increased due to increased in $\mathrm{K}$ uptake (Table 3). Maximum $\mathrm{K}^{+} / \mathrm{Na}^{+}$ ratio was observed in Bhitai followed by NIAB-I076, NIAB-41 and Khirman.

Table 1: Effect of external K application on shoot and root length (cm.) under salinity ( $\mathrm{NaCl}$ ) stress

\begin{tabular}{|c|c|c|c|c|c|}
\hline Genotypes & Control & $\begin{array}{c}\text { Control } \\
+ \\
(10 \mathrm{mM} . \mathrm{KCl})\end{array}$ & $\begin{array}{c}\mathrm{NaCl} \\
(100 \mathrm{mM} .)\end{array}$ & $\begin{array}{c}\mathrm{NaCl}(100 \mathrm{mM} .) \\
+ \\
\text { (10 mM. KCl) }\end{array}$ & Mean \\
\hline \multicolumn{6}{|c|}{ Shoot length (cm.) } \\
\hline Khirman & 15.51 & 17.53 & 14.67 & 15.93 & $15.97 \mathrm{~b}$ \\
\hline NIAB-41 & 16.50 & 19.33 & 15.97 & 17.30 & $17.27 \mathrm{a}$ \\
\hline Bhitai & 18.10 & 21.1 & 16.53 & 17.93 & $18.42 \mathrm{a}$ \\
\hline NIAB-1076 & $16.63 \mathrm{j}$ & 20.07 & 15.47 & 17.27 & $17.36 \mathrm{a}$ \\
\hline NIAB-886 & 14.43 & 13.43 & 12.47 & 11.93 & $13.07 \mathrm{e}$ \\
\hline RWM-9313 & 15.83 & 17.47 & 15.57 & 14.27 & $15.78 \mathrm{bc}$ \\
\hline Sarsabz & 15.29 & 17.59 & 15.36 & 14.99 & $15.81 \mathrm{bc}$ \\
\hline H.T.-29 & 14.62 & 17.07 & 13.16 & 13.71 & $14.64 \mathrm{~cd}$ \\
\hline H.T.-37 & 14.67 & 16.60 & 14.03 & 12.53 & $14.46 \mathrm{~d}$ \\
\hline ESW-9525 & 11.6 & 12.53 & 11.87 & $11.30 \mathrm{~s}$ & $11.82 \mathrm{f}$ \\
\hline Mean & $15.32 \mathrm{~b}$ & $17.27 \quad \mathrm{a}$ & 14.54 & $14.72 \mathrm{c}$ & \\
\hline \multicolumn{6}{|c|}{$\operatorname{LSD}(0.05)=1.42$} \\
\hline \multicolumn{6}{|c|}{ Root length (cm.) } \\
\hline Khirman & 15.33 & 15.40 & 12.60 & 13.00 & $14.08 \mathrm{ab}$ \\
\hline NIAB-41 & 12.93 & 13.60 & 11.27 & 11.07 & $12.22 \mathrm{bc}$ \\
\hline Bhitai & 16.27 & 16.47 & 13.60 & 13.73 & $15.02 \mathrm{a}$ \\
\hline NIAB-1076 & 18.33 & 16.13 & 14.33 & 12.17 & $15.24 \mathrm{a}$ \\
\hline NIAB-886 & 14.20 & 12.57 & 8.57 & 8.53 & $1097 \mathrm{~cd}$ \\
\hline RWM-9313 & 10.53 & 15.57 & 10.43 & 9.91 & $11.61 \mathrm{c}$ \\
\hline Sarsabz & 13.79 & 14.29 & 10.55 & 7.77 & $11.60 \mathrm{c}$ \\
\hline Н.Т.-29 & 15.73 & 13.26 & 7.87 & 8.72 & $11.40 \mathrm{c}$ \\
\hline H.Т.-37 & 12.10 & 12.50 & 8.47 & 10.23 & $10.82 \mathrm{~cd}$ \\
\hline ESW-9525 & 9.10 & 11.17 & 8.32 & 8.60 & $9.28 \mathrm{~d}$ \\
\hline Mean & $13.83 \mathrm{a}$ & $14.10 \mathrm{a}$ & $10.59 \mathrm{~b}$ & $10.37 \mathrm{~b}$ & \\
\hline
\end{tabular}

Means sharing same letters do not differ significantly at the $5 \%$ level of significance according to DMRT 
Table 2: Effect of external K application on Sodium $\left(\mathrm{Na}^{+} \%\right)$ and Potassium $\left(\mathrm{K}^{+} \%\right)$ contents in shoot under salinity $(\mathrm{NaCl})$ stress

\begin{tabular}{|c|c|c|c|c|c|}
\hline Genotypes & Control & $\begin{array}{c}\text { Control } \\
+ \\
(10 \mathrm{mM} \mathrm{KCl})\end{array}$ & $\begin{array}{c}\mathrm{NaCl} \\
(100 \mathrm{mM})\end{array}$ & $\begin{array}{c}\mathrm{NaCl}(100 \mathrm{mM}) \\
+ \\
(10 \mathrm{mM} \mathrm{KCl})\end{array}$ & Mean \\
\hline \multicolumn{6}{|c|}{ Sodium $\left(\mathrm{Na}^{+} \%\right)$} \\
\hline Khirman & 0.22 & 0.19 & 1.00 & 0.68 & $0.52 \mathrm{bc}$ \\
\hline NIAB-41 & 0.19 & 0.22 & 1.15 & 0.69 & $0.56 \mathrm{~b}$ \\
\hline Bhitai & 0.12 & 0.15 & 0.58 & 0.48 & $0.33 \mathrm{e}$ \\
\hline NIAB-1076 & 0.20 & 0.20 & 1.15 & 0.59 & 0.54 bc \\
\hline NIAB-886 & 0.19 & 0.18 & 0.88 & 0.73 & $0.49 \mathrm{bcd}$ \\
\hline RWM-9313 & 0.19 & 0.20 & 1.22 & 1.05 & $0.67 \mathrm{a}$ \\
\hline Sarsabz & 0.18 & 0.18 & 0.84 & 0.71 & $0.48 \mathrm{bcd}$ \\
\hline H.T.-29 & 0.14 & 0.19 & 0.68 & 0.62 & $0.41 \mathrm{dc}$ \\
\hline H.T.-37 & 0.17 & 0.20 & 0.68 & 0.58 & 0.41 de \\
\hline ESW-9525 & 0.20 & 0.22 & 0.71 & 0.67 & $0.45 \mathrm{~cd}$ \\
\hline Mean & $0.18 \mathrm{c}$ & $0.19 \mathrm{c}$ & $0.89 \mathrm{a}$ & $0.68 \mathrm{~b}$ & \\
\hline \multicolumn{6}{|c|}{$\operatorname{LSD}(0.05)=0.245$} \\
\hline \multicolumn{6}{|c|}{ Potassium $\left(\mathrm{K}^{+} \%\right)$} \\
\hline Khirman & 1.50 & 5.05 & 1.47 & 3.80 & $2.95 \mathrm{~cd}$ \\
\hline NIAB-41 & 1.63 & 5.37 & 1.52 & 4.32 & $3.21 \mathrm{abc}$ \\
\hline Bhitai & 1.50 & 5.98 & 1.55 & 4.83 & $3.47 \mathrm{ab}$ \\
\hline NIAB-1076 & 1.70 & 4.72 & 1.79 & 4.92 & 3.28 abc \\
\hline NIAB-886 & 2.33 & 5.08 & 1.99 & 3.45 & 3.22 abc \\
\hline RWM-9313 & 2.05 & 6.18 & 1.66 & 4.37 & 3.57 a \\
\hline Sarsabz & 1.34 & 4.43 & 1.45 & 3.20 & $2.61 \mathrm{~d}$ \\
\hline H.Т.-29 & 1.37 & 4.00 & 1.73 & 3.19 & $2.57 \mathrm{~d}$ \\
\hline H.T.-37 & 1.55 & 4.93 & 1.91 & 4.22 & 3.15 abc \\
\hline ESW-9525 & 1.74 & 4.50 & 2.20 & 3.58 & 3.03 bcd \\
\hline Mean & $1.67 \mathrm{c}$ & 5.025 a & $1.728 \mathrm{c}$ & $3.998 \mathrm{~b}$ & \\
\hline
\end{tabular}

Means sharing same letters do not differ significantly at the $5 \%$ level of significance according to DMRT

Table: 3. Effect of external Kapplication on K/Na ratio in shoot under salinity ( $\mathrm{NaCl}$ ) stress

\begin{tabular}{|c|c|c|c|c|c|}
\hline Genotypes & Control & $\begin{array}{c}\text { Control } \\
+ \\
(10 \mathrm{mM} \mathrm{KCl})\end{array}$ & $\begin{array}{c}\mathrm{NaCl} \\
(100 \mathrm{mM})\end{array}$ & $\begin{array}{c}\mathrm{NaCl}(100 \mathrm{mM}) \\
+ \\
(10 \mathrm{mM} \mathrm{KCl})\end{array}$ & Mean \\
\hline Khirman & 6.81 & 26.58 & 1.47 & 5.59 & 10.1125 \\
\hline NIAB-41 & 8.58 & 24.41 & 1.32 & 6.26 & 10.1425 \\
\hline Bhitai & 12.5 & 35.8 & 2.67 & 10.06 & 15.2575 \\
\hline NIAB-1076 & 8.5 & 23.6 & 1.35 & 8.34 & 10.4475 \\
\hline NIAB-886 & 12.26 & 28.22 & 2.26 & 4.73 & 11.8675 \\
\hline RWM-9313 & 10.79 & 30.9 & 1.36 & 4.16 & 11.8025 \\
\hline Sarsabz & 7.44 & 24.61 & 1.73 & 4.5 & 9.57 \\
\hline Н.Т.-29 & 9.79 & 21.05 & 2.54 & 5.15 & 9.6325 \\
\hline H.Т.-37 & 9.12 & 24.65 & 2.81 & 7.28 & 10.965 \\
\hline ESW-9525 & 8.7 & 20.45 & 3.1 & 5.34 & 9.3975 \\
\hline Mean & 9.449 & 26.027 & 2.061 & 6.141 & \\
\hline
\end{tabular}

\section{Discussion and Conclusion}

Salt tolerance in the Triticeae is associated with enhanced ability to discriminate between $\mathrm{Na}^{+}$and $\mathrm{K}^{+}$in the soil solution and to preferentially accumulate $\mathrm{K}^{+}$and exclude $\mathrm{Na}^{+}$(Omielan, et aI., 1991 and Ali, et al., 2004). In the present study, almost all the wheat genotypes responded varyingly to external potassium application. Wheat genotypes Bhitai, NIAB-I076, NIAB-41 and Khirman showed better performance in terms of shoot and roots growth. 
Better performance of these genotypes might be due to quick response to $\mathrm{K}^{+}$application, especially in case of NIAB-41, NIAB-I076 and Khirman which were showing high $\mathrm{Na}^{+}$at $100 \mathrm{mM} \mathrm{NaCl}$, but due to the application of external potassium its concentrations decreased significantly. The lower concentrations of $\mathrm{Na}^{+}$by these genotypes might be due to the competition between $\mathrm{Na}^{+}$and $\mathrm{K}^{+}$at the uptake sites of plasmalemma, resulting in high $\mathrm{K}^{+} / \mathrm{Na}^{+}$ratios i.e. 10.06, 8.34, 6.26 and 5.59 in Bhitai, NIAB-1076, NIAB-41 and Khirman, respectively. Gorham et al, (1987), Sarwar, et al. (2003) reported that in wheat genetic variation in salt tolerance is associated with low rates of salt transport to shoot [especially low rates of $\mathrm{Na}^{+}$transport and high selectivity for $\mathrm{K}^{+}$ over $\mathrm{Na}^{+}$. On the other hand, the genotype NIAB886, RWM-9313, HT-37 and Sarsabz although have low $\mathrm{Na}$ accumulation under salinity (100 mmol NaCl $\mathrm{dm}^{-3}$ ), responded poorly to external $\mathrm{K}$ application. This indicates their less discriminating ability between $\mathrm{Na}^{+}$and $\mathrm{K}^{+}$. The $\mathrm{K}^{+} / \mathrm{Na}^{+}$ratio in these genotypes ranges from 5.34 to 4.16 . The genotype HT-29 has also showed high $\mathrm{K}^{+} / \mathrm{Na}^{+}$ratio, but was showing low growth performance, which indicates that the mechanism responsible for enhanced $\mathrm{K}^{+} / \mathrm{Na}^{+}$ discrimination is not activated even at high $\mathrm{K}^{+} / \mathrm{Na}^{+}$ ratio (7.28). It has been reported that the $\mathrm{K}^{+} / \mathrm{Na}^{+}$ discrimination character enhances a process that is already operating in cereal roots and to a greater or lesser extent in the plant roots of all plants (Ashraf and Sarwar, 2002, Gorham et al., 1985 and Jeschke, 1984). Physiologically it is a quantitative rather than a qualitative phenomenon, although weather it affects an existing transport process or superimposes a new mechanism is yet to be established (Gorham, 1990; Kamal et al., 2003).

\section{References}

Ali Y., Aslam Z., Ashraf M. Y. and Tahir G. R., (2004). Effect of salinity on chlorophyll concentration, leaf area, yield and yield components of rice genotypes grown under saline environments. Inter. J. Environ. Sci. Tech., 1, 229-234.

Ashraf M. Y. and Sarwar G., (2002). Salt tolerance potential in some members of Brassicaceae. Plysiological studies on water relations and mineral contents. In prospects for Saline Agriculture. R. Ahmad and K. A. Malik (Eds.) Kluwer Academic Publishers Netherlands, 237-245.

Epstein E., (1966). Dual pattern of ion absorption by plant cells and by plants. Nature, 212, 1324-1327.
Gorham 1., McDonnell E., Budrewics E. and Wyn Jones R. G., (1985). Salt tolerance in the Triticeae: Growth and solute accumulation in leaves of Thinopyrum hessarabicum. J. Expt. Bot., 36, 1021-103.

Gorham 1., Hardy C., Wyn Jones R. G., Joppa L. R. and C. N. Law, (1987). Chromosomal location of a K/Na discrimination character in the $D$ genome of wheat. Theor. Appl. Gen., 74, 584-588.

Gorham L., (1990). Salt tolerance in the triticeae. Ion discrimination in rye and Triticales. J. Expt. Bot., 41, 609-614.

Jeschke W. D and Nassery H., (1981). $\mathrm{K}^{+}-\mathrm{Na}^{+}$selectivity in roots of Triticum, Helianthus and Allium. Physiol. Plant., 52, 217-224.

Jeschke W. D., (1984). K-Na exchange at cellular membranes, intracellular compartmentation of cations, and salt tolerance. In salinity tolerance in plants: Strategies for crop improvement, Ed. RC. Staples. John Wiley and Sons, Inc., New York, 37-66.

Kamal A., Qureshi M. S., Ashraf M. Y., and Hussain M., (2003). Salinity induced changes in some growth and physio-chemical aspects of two soybean [Glycine max (l.) Merr.] genotypes. Pak. J. Bot., 35, 93-97.

Mass E. Y. and Hoffman G. J., (1977). Crop salt tolerancecurrent assessment. 1. 1m. \& Drainage Division. Am. Soc. Civil Eng., 103, 103-134.

Munns R., Greenway H. H. and Kirst G. O., (1983). Halotolerant. In: Physiological Plant Ecology III. Response to the Chemical and Biological Environment. Lang, O. L., P. S. Nobel, C.B. Osmond and H. Ziegler (Eds). Encycl. Plant Physiol. New Ser., 12, 59-135.

Omielan J. A. and Epstein E., (1991). Salt tolerance and ionic relations of wheat as affected by chromosomes of salt tolerant Lophopyrum elongatum. Genome., 34, 961-974.

Sarwar G., Ashraf M. Y. and Naeem M., (2003). Genetic variability of some primitive bread wheat varieties to salt tolerance. Pak. J. Bot., 35, 771-777.

Shah S., Gorham I., Forster B. P. and Wyn Jones R. G., (1987). Salt tolerance in the triticeae: the contribution of the $D$ genome to cation selectivity in hexaploid wheat. J Expt. Bot., 38, 254-269. 